\title{
OSTREA ISOGONUM.
}

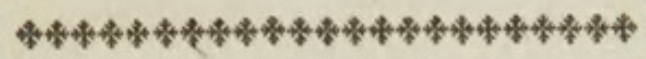 \\ CHARACTER GENERICUS.}

Animal Tethys.

Tefta bivalvis, (plurimis) inæquivalvis, fubaurita. Cardo edentulus, foffula cava ovata ftriifque lateralibus tranfverfis.

\section{CHARACTER SPECIFICUS, Sic.}

OSTREA, tefta æquivalvi, lobo laterali majore, cardine multoties fulcata.

$$
\text { Lin. Syf. Nät. p. } 1149 .
$$

Oftrearum genus, quo nomine eas folummodo intelligimus quas titulo oftrearum rudium diftinxit Linnæus, (exclufis iis quæ pectines vocantur,) varias continet fpecies facie inter fe valde diflimiles. Ex iis quæ ob formam notatu digniflimæ funt, fpeciem naturali colore et magnitudine repræfentat tabula oceani Indici incolam. 


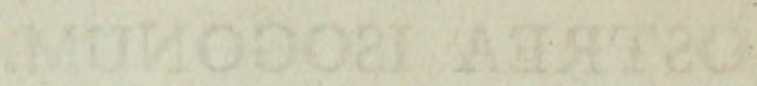

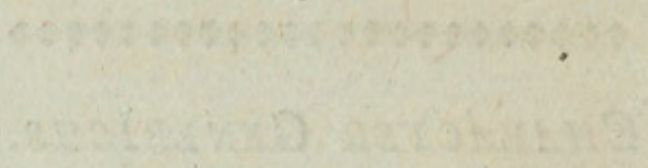

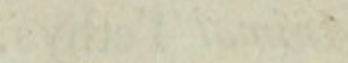
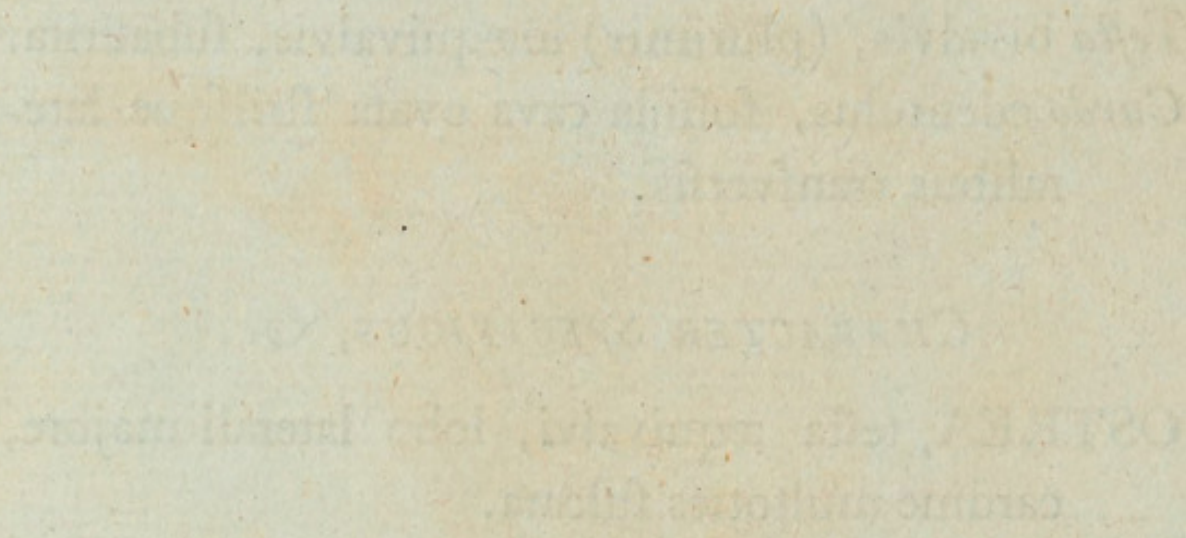



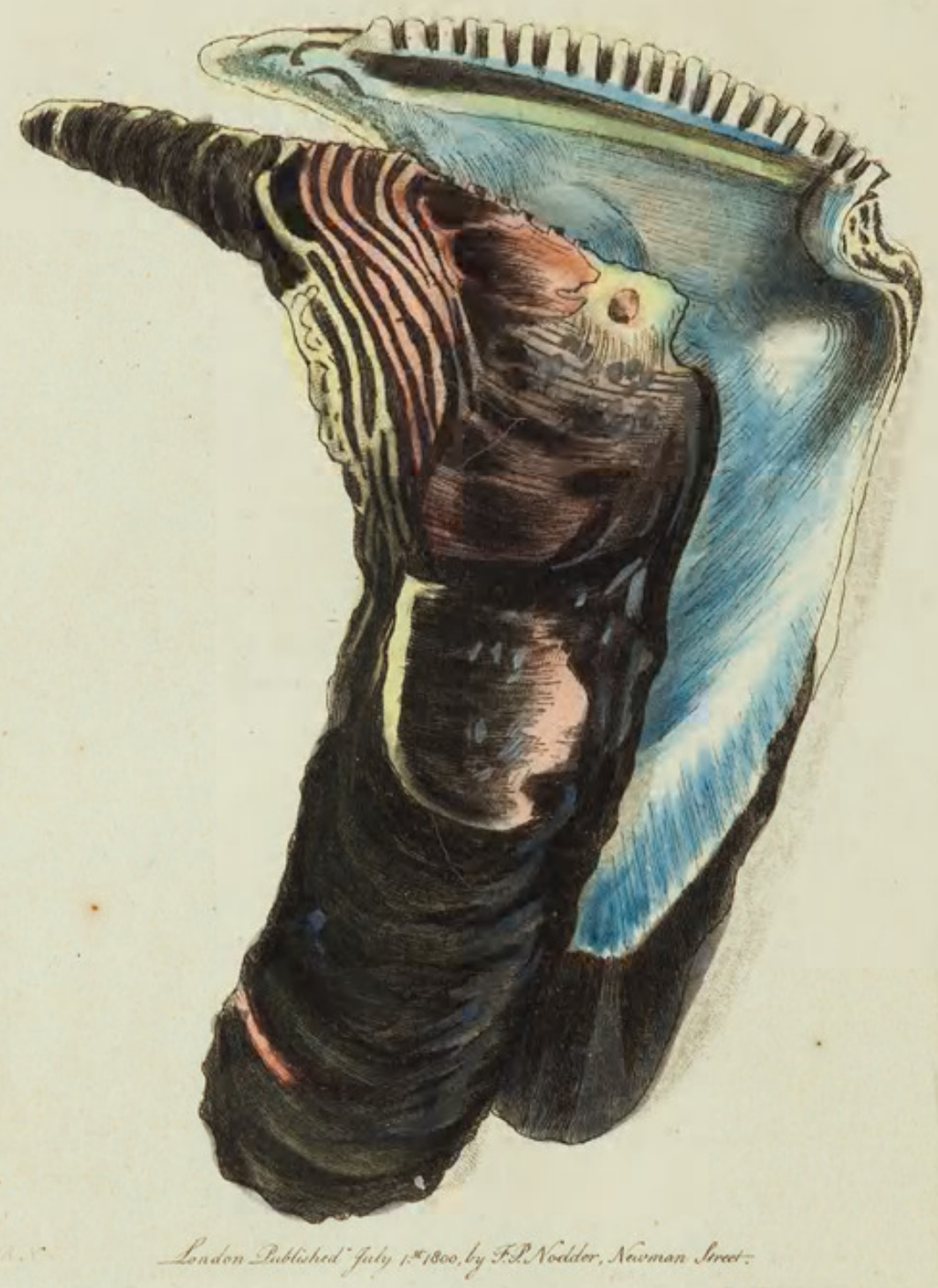




\section{THE}

\section{LONG OYSTER.}

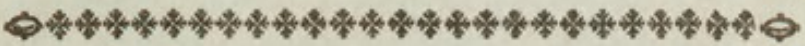

\section{GENERIC CHARACTER.}

Animal refembling a Tethys.

Sbell bivalve (in mort fpecies unequally), fubauriculated.

Hinge toothlefs, with an ovate foffule and lateral tranfverfe ftreaks.

\section{SPECIFIC CHARACTER, छC.}

Equal-valved OYSTER, with the right lobe largeft, and the hinge marked by numerous furrows.

The genus Oftrea, by which is here meant the affortment called by Linnæus Oftree rudes, (excluding the Pectines or Efcallops,) contains feveral fpecies which differ confiderably in point of habit from each other. Among the moft ftriking as well as curious is that reprefented on the plate, which is a native of the Indian ocean. Its general fize and color are as expreffed in the figure. 


\section{$2 \mathrm{BHL}$ Biodiversity Heritage Library}

Shaw, George. 1800. "The Long Oyster, Ostrea isogonum [PI. 439]." The Naturalist's Miscellany 11(CXXXI), https://doi.org/10.5962/p.310886.

View This Item Online: https://www.biodiversitylibrary.org/item/276496

DOI: https://doi.org/10.5962/p.310886

Permalink: https://www.biodiversitylibrary.org/partpdf/310886

\section{Holding Institution}

Museums Victoria

\section{Sponsored by}

Atlas of Living Australia

\section{Copyright \& Reuse}

Copyright Status: Public domain. The BHL considers that this work is no longer under copyright protection.

This document was created from content at the Biodiversity Heritage Library, the world's largest open access digital library for biodiversity literature and archives. Visit BHL at https://www.biodiversitylibrary.org. 